\title{
Waiting to be Cinderella'd?: Attitudes on Class Differences Among Women
}

\author{
Leila Wood \\ Carol Hostetter \\ Sabrina W. Sullenberger
}

\begin{abstract}
This article explores the way in which college students construct attitudes about class differences among women. Social work student researchers interviewed 30 college students at a Midwestern public university and asked them to tell stories about women in two different social class positions. The results revealed that social class differences are constructed based on factors related to family of origin, personality, structural inequities, personal choices and relationships, as well as other intersecting experiences. In addition, participant stories highlighted gendered attitudes towards women in poverty. Implications for social science teaching, practice, and research are discussed.
\end{abstract}

Keywords: Feminization of poverty, gender, attitudes, college students, social class, social work

The economic status of women in the United States has been the frequent subject of social science research. While academics and helping professionals may be well aware of the intersecting forms of oppression faced by women, less is known about people's beliefs about females in different class positions. Attitudes inform action (Cozzarelli, Wilkinson, \& Tagler, 2001) so a lack of knowledge about perceptions of gender and social class creates a deficit in the ability to work for social justice, especially regarding women experiencing poverty. An exploration of how people view differences between a woman in an uppermiddle class position and one living in poverty can reveal the factors that help to shape such attitudes. Information about perceptions of women and economic status can be used to inform social work research and practice in order to reduce disparities and stigma for women in different social class positions. Of particular importance is how college students form beliefs about social justice issues as they are getting ready to enter the workforce, where they will have influence on the experiences of women in various social class positions. This study focuses on the findings of a research project aimed at exploring how college seniors create indicators of social class. The research team asked participants to construct stories about women in two different social class positions: one a janitor or factory worker and the other a successful business person. The narrative from the participant interviews illuminates some of the ways that gendered beliefs about social class are determined and constructed. These findings have important implications for social science research, teaching, and practice.

Leila Wood, LMSW, Ph.D., is an Assistant Professor in the Texas State University School of Social Work in San Marcos, TX; Carol Hostetter, Ph.D., is a Professor in the Indiana University School of Social Work in Bloomington, IN; and

Sabrina W. Sullenberger, Ph.D., is an Associate Professor and Chair of the Social Work Department at Belmont University in Nashville, TN.

Copyright (C) 2014 Advances in Social Work Vol. 15 No. 2 (Fall 2014), 460-479 


\section{Literature Review}

\section{The Role of Gender in Social Class}

Since the 1970s, researchers have noted a decidedly feminine trend in poverty (Richards, Garland, Bumphus, \& Thompson, 2010; Tiamiyu \& Mitchell, 2001), with women experiencing more poverty than men. This "feminization" of poverty is cemented by experiences of single parenthood, domestic violence, lack of affordable housing, poor job opportunities, and inadequate public welfare (Richards et al., 2010; Tiamiyu \& Mitchell, 2001). At the same time, wealth in America has increasingly become concentrated, making class mobility more difficult (Froehlich, 2005). In addition, job polarization with economic growth only at the top and bottom of the labor market has led to a decrease in middle-class incomes. The increase of women entering the workforce has created more opportunities in the upper and middle class among females with a college education, but has put greater strain on those in poverty (Dwyer, 2013). In 2012, 16\% of American women were living in poverty, and $28 \%$ of female-headed families had incomes below federal poverty lines (U. S. Census Bureau, 2012; U. S. Bureau of Labor Statistics, 2012). An additional $7.6 \%$ of women qualify as working poor (U. S. Bureau of Labor Statistics, 2012). Women of color experience a more hostile labor climate, influenced not only by pervasive sexism, but racism as well. Poverty rates for women of color are double those of white women (Ahmad \& Iverson, 2013). These data suggest that women are vulnerable to poverty and to other social class issues, such as racism.

Disparities in pay in the labor force play a large role in the feminization of poverty. Analysis of the gender wage gap in the United States revealed that in 2011, women earned only $77 \%$ of male counterparts, despite strong family reliance on their earnings (American Association of University Women [AAUW], 2014b). The Pew Research Center recently gave the name breadwinner moms to women, married or single, who have children under the age of 18 and provide the sole or primary income for their family (Wang, Parker, \& Taylor, 2013). Breadwinner moms share responsibility for their families' livelihood, but differ dramatically in income levels with poor women making considerably less than male counterparts (Wang et al., 2013). Inequities in the labor force stemming from gendered discrimination and changes in national policy are seen as a source of the feminization of poverty. An increased expectation, propelled by the Personal Responsibility and Work Opportunity Reconciliation Act and subsequent welfare restructuring in 1996, that lowerincome mothers enter the workforce has shifted policy closer to devaluing the work traditionally done in the home (Froehlich, 2005). Women entering the workforce in lowpaying jobs may face occupational injustice and "occupational imbalance," meaning that they have more labor commitments than others in higher class positions (Froehlich, 2005, p. 406). This occupational injustice can be compounded when women are part of other historically marginalized groups and encountering multiple forms of oppression. Part of this imbalance stems from mothers entering the workforce while continuing multiple forms of labor at home as well as from the influx of women into low-wage care taking professions that were historically done in the home, such as childcare (Dwyer, 2013; Froehlich, 2005; Gittell, 2009). Women have higher educational attainment now than at any point before, but face struggles exiting and re-entering the work force when they have families (Gittell, 
2009). Overall, white and Asian women make more money with comparable educational backgrounds than black or Hispanic women (AAUW, 2014a). Men of color out earn their female peers within their ethnic group, and white men out earn all groups of women (AAUW, 2014a).

The feminization of poverty and its impact on the lives of women is not new news in social science research. While some women have been able to make enormous economic strides, those living in poverty and especially mothers have been unable to achieve meaningful class mobility. Impacting their experiences are societal attitudes and expectations, which is an area of study that merits more attention

\section{Attitudes About Gender and Poverty}

Research on beliefs about poverty is important because beliefs shape attitudes and behavior, including civic participation (Cozzarelli et al., 2001; Davidson, 2009). Opinions about social issues reflects public discourse, which often reflects generational beliefs and political action (Foster, 2008). Analyses of many social surveys and census data have indicated that race and class standing influence beliefs about poverty attributions (Adeola, 2005; Foster, 2008). Caucasians and people from middle class backgrounds are more likely to have individualist views of social class, while African Americans and those in lower income brackets are more likely to have structural beliefs about the causes of poverty (Adeola, 2005; Foster, 2008). In a survey of 154 undergraduates, Abowitz (2005) found that college students believe in individualist causes of class mobility, including the idea of the American Dream, or that anyone can achieve a high class status with enough work.

Views on gender may impact poverty perceptions. In a sample of 575 college students, participant adherence to traditional gender roles and promotion of victim-blaming attitudes were connected to low support for social welfare spending, whereas promotion of feminist values was connected to stronger support of social welfare (Swank, 2005). Cozzarelli et al. (2001) surveyed over 200 undergraduates about their attitudes towards poor women and men. The sample had more positive beliefs about poor women than men in poverty. Poor women were seen as having more positive characteristics, but also as having too many children. Participants' attributions for men in poverty were internal in nature, while attributions for women were individual and culturally based. Attributions for social class among men matched the research team's previous survey when no gendered pronoun was given suggesting that attitudes about male poverty are closer to general attitudes as a "default" mode (Cozzarelli et al., 2001). These findings necessitate a closer look at constructions of social class among women, especially if attitudes towards men in poverty differ from those towards females. In particular, it is important to learn more about college students and their attitude constructions in light of emerging knowledge about human development. As social, emotional, and neurological development extends into emerging adulthood (Ashford \& LeCroy, 2013), inquiry focused on this age range may offer insights to assist in enhancing understanding about social class issues among this group. The following research project offers new insights into how college students construct femalespecific attitudes about class. 


\section{Methods}

\section{Research Question}

The research question guiding the inquiry was: How are social class differences among women constructed? The research question guided analysis by seeking to uncover the process by which people in the sample shape attitudes about class difference among females and construct meaning about how women achieve and maintain economic status.

\section{Procedure}

This study is unique in that, in addition to offering insight into constructions of social class, it served as a teaching tool to illustrate the research process to undergraduate social workers. Social work juniors at a large, Midwestern university, who were enrolled in a required introductory research course, located, recruited and interviewed study participants. The students were engaged in a semester-long, Institutional Review Board approved research project that also taught them skills for conducting social work research. This is a multi-year study aimed at gathering data towards a grounded theory about poverty attributions. For more information about the student learning process and an evaluation of this teaching method as a learning tool, please see Hostetter, Sullenberger, and Wood (2013). The inclusion criteria for participation were graduating seniors, between the traditional graduating age of 20 and 25. Study participants were found using a peer-swap style of snowball sampling in which one student found a participant for another student to minimize student use of close friends or relatives. These interviews took place at the location preferred by a participant and lasted anywhere from 15 to 30 minutes.

The interview consisted of questions based on two scenarios, one involving a woman who was described as working as a janitor or in a factory and struggling to get by, and the other of a woman who is the vice president of a successful business. These two sets of descriptive terms were meant to distinguish different social class experiences. A total of 30 participants were asked questions with a female pronoun and 25 participants were asked the questions with a male pronoun used in the scenario. For the current analysis related to constructions of women in poverty, a subsample of all 30 interviews using the female pronoun was used. Of the 30 college students interviewed with the protocol using "woman," 21 were female respondents and 9 were males. Ages ranged from 21 to 23 . The interviews were conducted by the undergraduate researchers, a doctoral student, and the two principle investigators. The interviewees represented an array of majors, from history to business and education. No further demographic information was taken. Social work majors were intentionally not sampled due to the heavy emphasis on social class differences in the social work curriculum.

\section{Analysis}

The data were analyzed using the grounded theory method. Grounded theory is a good fit for studies examining social processes (Annells, 1997). In grounded theory, data are analyzed using the constant comparison method, where items are compared to the instances that come before it and those that will come after it (Birks \& Mills, 2011; Charmez, 2006). 
This process leads to coding of the data. In this study, coding happened in three stages: open, or line-by-line coding, axial coding to build relationships, and advanced coding to construct theory (Charmez, 2006; Corbin \& Strauss, 2008). Open coding involves a careful line-by-line analysis of the data. The axial coding phase helps to build relationships and refine categories. In the advanced coding phase, the theory is constructed (Charmez, 2006; Corbin \& Strauss, 2008). Two researchers analyzed the data separately during the stage of open coding using the verbatim transcripts. Coding occurred using the constant comparison method. The codes emerged from the data, consistent with constructivist grounded theory (Charmez, 2006). The codes were merged by the same two researchers during the axial coding phase. The codes were analyzed for similarities and differences, and a third member of the research team was consulted about intersecting and divergent codes and interpretations. As this is an ongoing project, the third stage of analysis helped to develop themes that relate to ongoing theory construction about attitudes on poverty. The themes related to the gendered nature of poverty attributions among women were finalized in the advanced coding stage. Saturation was reached when subsequent data collection and analysis failed to reveal new insights.

Like many qualitative methods, grounded theory has procedures for rigor. Charmez (2006) details the four rigor criteria of a grounded theory study as creditability, originality, resonance, and usefulness. Use of memos from data collection and analysis formed an audit trail to monitor theory and thematic development. Creditability was established through use of thick descriptions coming from participant voices. All findings are rooted in saturated mention and comparison within and across the data and presented in the findings section below in order to verify their place in the conceptual framework. The previous year's findings and theoretically sensitizing literature indicated the originality of the line of inquiry and the need for the study focusing on gender. The participant's ability to use storytelling in order to shape the interview helped to establish resonance. The usefulness of the study will be illustrated for the benefit it provides for the social work students involved in the research project, as well as for the information gleaned from the findings. After analysis, use of existing literature helped to triangulate and contextualize the data.

\section{Findings}

College students in the sample expressed beliefs that the differences between women in lower socio-economic statuses, defined as struggling to get by as a janitor or factory worker, and those in the upper class position of being a successful vice president, were a combination of several related factors. A careful analysis of the data set and construction of related themes resulted in six related factors. These factors included cycling, or the generational transmission of social class status; choosing, or the implications of personal decision-making in class status; accessing, or the level to which women were able to have social and educational structure and support; identifying, or the importance of personality traits in achieving and maintaining financial success; relating, including the role of the relationships of the women described by the participants in shaping gender norms and social class status; and finally intersecting, or the impact of other identity positions in the construction of social class distinctions. Cycling, choosing, accessing, identifying, relating 
and intersecting made up the process by which participants constructed social class differences.

\section{Cycling}

Participants overwhelmingly asserted a generational aspect to social class, which is passed down from the family of origin, in particular, from the mother. For the woman described as financially struggling, storylines were frequently constructed around someone who came from a single-parent home. Chloe described succinctly the dominant story line for the low-income woman throughout the sample:

She kind of had a hard upbringing, she did not have both parents in the home so she's kind of repeating something that her mother went through with kind of struggling to make ends meet. She had children at a younger age, so now not only is she struggling to make ends meet, she's struggling to also feed her children. So, that's hard and there's no father figure around to kind of help her or guide her through what she's going through right now.

Generational poverty not only acts as a barrier to achieving economic goals, it also permeates to extended family, placing constraints on economic and social choices, and limiting the ability to access social support. For example, the needs of the family of origin can be a powerful draw to join the work force. Several times, participants referred to the need of the low-income woman in their story to begin work to help with siblings. Ariel explained why the lower-income woman in her story may not have gone to college:

...She had other siblings, so she couldn't focus on kind of that achievement, that academic achievement as much as like the feeling of trying to help with the household. So she could have possibly been the oldest child to an extent to where she kind of felt like, okay, I need to help my mom out, it's my responsibility. So she could have been forced to get a job at a young age, or, something like that.

This generational cycle of social class was seen by some participants as nearly impossible to escape, Rachel said, which makes class differences unfair.

Okay, they're not fair because you can't help the situation you're born into, you can't help, poverty, I see it as a vicious cycle. If you're stuck into it, it's really hard to get out of it, and I think that it's unfortunate because there are so many people that have so much potential, and they just don't get the opportunity to that potential because they're stuck in a situation they have no way out of.

For the woman working as a vice president, class positions were also generationally transmitted. Families not only pass down economic values, but also can provide support to maintain and gain class status. Women who grew up in middle or upper class families have the advantage of the ability to access networks from their family of origin. In addition to being able to access networks, the woman who grew up in a middle or upper class family was taught the value of education. Dionne told a story about the family of origin of a successful vice president. 
They were probably middle-class and more than likely she wasn't a first generation college student. She was able to fund college or her parents were able to fund college. She may have been smart enough to find the money that is out there for college students. In school I think she was a hard-working student that led to her success in college as well as in high school. She did whatever it took to be successful and that's why she is in the position she is in now.

Overall, while participants acknowledged the power of other factors, family of origin was identified as a major influence along with choices made by the individual in determining social class.

\section{Choosing}

Participants related that the women in the stories they constructed often made critical choices that solidified their financial positions and impacted the possibility for social mobility. Further, while circumstance can provide the initial class position, the path of decisions taken affects what happens later. Amber described the potential lost opportunity of class mobility:

She might be attending the local college or at some point in time have had attended the local college but if you're currently working as a janitor, I doubt that you struck it rich and just sorta decided to live a poor life by choice...And that's how it is, I think sometimes. It's not even money, it might be opportunity, it might be circumstances, I mean sometime you just can't make it there. But then other times, you're on Teen Mom 2 and you get knocked up and you just cannot be bothered to take your GED because you would rather lay up in bed with your good for nothing, ugly boyfriend named Adam, all day long.

Even when structural factors, such as lack of access to good education are a factor, participants told stories of women who made choices that ultimately limited their ability to have more economic security. Participant attitudes were influenced by the woman's attempts to gain status, as Jessica articulated:

It's not necessarily fair but it depends on the situation. Did the mom with less money try to go to college? Did she try to make her life better? Did she take the steps that you have to take to get to where you need to be or where you want to be to live a comfortable lifestyle?

Participants created a successful vice president who may have structural factors in her favor, but also makes the best possible choices to be poised for good class standing. Tonni talked about a woman in this position:

Still had a social life because in order to be a vice president you have to be social, but so she was probably popular I would say, but not too popular. That didn't overtake her whole life and she focused on school and went to college and tried to make her parents proud. Got a job right away and maybe worked her way up, met the right people, kept working her way up, switching jobs, getting promotions and here she is. 
The higher-income woman is viewed as more deserving of the quality of life she enjoys because she made the right choices, as expressed by Becky:

Like if the women that owns her own company worked very hard, went through school, tried very hard to get good grades. Like built her company from the ground up and she worked very hard for that then she deserves it.

The stories told by participants reflected choice as a critical element of class status. Decisions may be impacted by structural barriers, but participants viewed being poor as ultimately a lifestyle choice of someone who did not try hard enough to escape poverty. In addition to personal choices, access to resources and support were seen as critical in class status.

\section{Accessing}

Class differences between the two women were seen in part as a matter of accessing resources, such as social support and education. The lower-income woman was conceived of as lacking support to pursue education and other goals. Women growing up in lowincome homes were seen as having little or no access to higher education, as well as coming from families who placed limited value on college. This limits their ability to achieve mobility, as Cora elaborated:

I think that she completed her GED; she has a high school degree. A diploma. And I think probably she didn't have all the same opportunities as other people did. I think maybe she came from a working class background; with her parents anyway.

They were working class as well. And so, she has kind of limited mobility.

The low-income woman is also one who lacks social support from her family of origin, as Becky explained:

As for the one that works in the factory I think the difference for her would be maybe not having that much of a support system. Because either they are too far away or she is not that close with them. She gets less time with her family I think.

In juxtaposition, the higher-income woman has supportive social networks and educational help. This often stems from the support of active family and peer networks, which offer models for success, as Ariel noted:

She probably had a better support system, especially at home because I feel like when you don't have it at home and your parents aren't there then it kind of makes it hard for you to be driven or to feel more comforted and supported. But I imagine her having that and also I imagine her having a better group of friends maybe at a younger age or in high school.

Support from family and friends and the ability to gain resources helps women stay in middle and upper class positions, in addition to individual personality traits. 


\section{Identifying}

Personality emerged as an important aspect of social class construction for women. Participants carved out a definite personality type for a higher-income woman. The female vice president was narrated as powerful, focused, and confident. She is perceived, as Olivia put it, as having a strong personality.

She's probably has a very strong personality for becoming a vice president of her company. It takes a strong woman to become a leader within a company.

The higher income woman was often described as coming from a more affluent family of origin, which also shaped personality. In order to achieve her goals, she had the support of her family and social personality. These leadership skills are honed through extensive training and academic work, but as Ariel noted, personality counts in how well a woman could perform the role of being vice president of a business.

It takes a lot to be a VP. It takes a certain personality and qualities to be a leader, you have to be confident, you have to be motivating, very on top of things and organized, so I see her being president of union board at (her university) or something like that. Just a very high up position.

Amber noted that a successful woman is not necessarily a "soft" woman.

Um, you're looking at 2 to 3 degrees and you're looking at a very extensive resume and experience. You're also looking at someone who has the ability to kind of like, be that softer woman but, um, also take no bullshit in the, in the in the board room so to speak. She's not coming in there, she's not coming in there ready to play with the kids or to go get her nails done - she's coming in there ready for business because she has to earn that respect.

Physical appearance and presentation was an indication of personality, especially for higher income women. The vice president was defined by her use of feminine indicators of social class. Harper described what the woman in her story would wear.

A lot of business woman gear, a lot of jewelry to show that she's feminine. I mean I would have some high heels personally.

Less mention was made about the personality of the woman in the story working in a lower class position. A handful of participants indicated that she probably would be a woman of color. A couple of interviewees also indicated that she might not be physically attractive or fit. When it was alluded to, the personality of the woman in the lower-class position was constructed as milder, more traditionally feminine. The vice president was described by participants as tough, demanding, and calculating In addition to personality, participants indicated that women's relationships affected how they gain class status, but more importantly, how they maintain their social position.

\section{Relating}

Relationships were the most unifying indicator of class status among women in the sample. They were conceived of in many forms, including the parenting role, relationship 
with family of origin, friends and peers, and marriage. The quantity and quality of relationships were major factors affecting social class from an early age. Several participants indicated that the lower-income woman had experienced violence in her past, as Eddie stated when describing her relationships:

She is closest to her mom's family because she was never really close with her dad because he abused her.

The vast majority of the sample also indicated the lower-income woman's family structure was that of a single mother raising children without financial or emotional support from the father of her children. Herbert's comment on family structure matched much of the sample.

I'd probably characterize her as like single mother, either divorced or widowed in sort of a, a type of manual labor or service job, working in either, maybe having more than one job but not really a kind of well paying, stable career.

Most low-income women were viewed as having children who lived with them. Thus, in the case of the lower-income woman, the quality of parenting became a major issue explored in participant interviews. Many participants, such as Krista, imagined the work life of the woman to negatively impact her children.

Yeah, for the woman who is a janitor. She probably is not as involved in the children's schooling. Maybe she doesn't really expect great grades or make sure they're in extra-curricular activities. Maybe, the kids even help support the mom or family.

The contrast of the two class positions of the women described by participants was clearest when it came to parenting roles, as summed up by Eddie:

They are always thinking for providing for the kids as they grow up. The rich woman is thinking about college, while the poor woman is thinking about where dinner is going to come from.

The successful vice present was described as having strong relationships. These relationships often stemmed from a supportive family of origin. The sample however, was split on the issue of marriage for the vice president. Some participants, like Grace, imagined her as married with children.

Okay well I envision this person since she's vice president, you know, in a big luxury house, a lot of land, probably a nuclear family I would think. With the husband but she would be the bread winner too. So he might work also. I'd say they both work and then the children, they're in a, you know, high pre-school or you know a really prestigious school, any of the children they might have.

Others, like Jacob, imagined a woman with no children.

She lives in an apartment in the city. Um, she doesn't have any kids or anything like that, she's basically just kind of a career woman, and that's how she likes it. 
One critical element of social class construction in the sample was that a successful middle- or upper-class woman is more able to control the relationships in her life, including the decision to raise children or get married. Freedom over reproduction was a major factor influencing how participants constructed class differences among women. Having children was seen as a major expense, and one that influenced social class position. The ability to evaluate the cost of raising children and wait until a person could afford to have children was seen as a critical element of class status among woman. Jessica described a successful woman who made the right moves:

She is probably doing smart things with her money. Saving and planning. She probably has a nice car and can afford the gas to get to and from work. She probably graduated from college to get that position. Maybe she is married and maybe she has kids. If she does then she can afford to have kids. She can afford for them to have a pretty good life.

Being able to afford quality care and possessions for children, and to watch them grow, was considered a luxury of the middle and upper class. However, participants acknowledged the struggles of women in all class brackets of managing many competing roles.

\section{Intersecting}

Participants in this study imagined social class differences in part based on the intersection of different roles and identity positions held by women. Some participants saw the intersection of roles as a work and life balance issue. Amber described the plethora of roles that a woman must play and the challenge of the pressure to be everything:

What's interesting is when I think of both the first and the second scenario, I think that woman is a go-getter and I feel like we already talked about music so much Shania Twain has a song where, um, she's describing different women and she says, um, you know, she's your, she's your bagger at the local grocery store, she's your mom, she's your, she's your doctor and women these days - just like, as a gender - are expected to be so many different things and you can't be just a stay at home mom. You have to be the stay at home mom and the P.T.O. president and, you know, such the faithful wife who's got dinner on the table by seven o' clock and kids in bed by $9 \mathrm{pm}$ and homework in backpacks and you also have to go to all the soccer games and you also have to go to all the softball games. And you have to be so many different people at so many different times and be willing to wear so many different hats and to do it well.

For the vice president, participants imagined success as having a comfortable work-life balance and financial security. The lower-income woman's life is out of balance from the pressure of the many roles she must take. The participants in this study imagined many possible successes for middle or upper class women, and several challenges for one working as a janitor or in a factory. However, many participants saw how in both class positions, women face obstacles. The pressure of gender roles and norms adds stress to women in all class positions. Amber related the intersection of class and gender roles, and the expectations of physical appearance. 
It's really hard to have your cake and eat it too as a woman. Men can go out and be doctors and in their free time go over to happy hour and they're done for the night. Whereas a woman, you're getting off of work... Like, you can't be walking up in the club competing with other people looking a hot mess...So it's just like really hard to be that woman that like has it all and maintain it all, and do it well.

Ariel mused that no matter how hard the vice president might work, she will still be compared to her male counterparts.

I think just that she has the qualities and she can do her job just as well as if a male were in her position. Because I know now a lot of corporation, now I don't know if it's a large business or small business but I think it's hard for a women to prove themselves when they already have people prejudging the situation before they have even had a chance to prove themselves, people already have these judgments. So I think she is probably already really stressed out about proving herself already and she's probably almost doing everything times a million to do everything better.

Despite the resiliency and independence of women in either class position in this sample, participants endorsed the idea that many women are looking for partnerships with men to improve or change their economic circumstances. Eve declared what she saw as the two options for class mobility for women:

Because as women, unfortunately it goes back to like luxury and opportunity and privilege and either you're studying to get a diploma or you're studying to get a man with a diploma.

For a struggling woman, this was often described to be a failed attempted at a marriage relationship to escape from poverty, as Jacob indicated.

She saw a way out with, you know, getting married to her guy, and was like, ok, were going to be alright, but it didn't turn out to be that way.

When the marriage does not work out, as Mallory conveyed, the results are poverty, and single-parenthood.

So we're going to say she's a mother, supporting two children, the first one out of wedlock. That didn't turn out so well. The father is “M.I.A.," or at least not paying child support, and she has to support two kids

Participant views on marriage and coupling suggest that women look for partners that will improve or at least help them to maintain their class status. The ability to provide financial support was seen as a deciding factor about a romantic relationship. Amber attributed this desire to partner for financial gain as part of an innate desire to be cared for, or have a Cinderella story.

...Girls are designed to be caretakers and so part of being a woman is just that innate desire to be taken care of. And that's not necessarily living up in a mansion and getting, you know, big ole bitty breast implants, BUT it is that, you know, you're going to one day have kids and you're going to one day wanna be taken 
care of and you're not going to want to have to worry about bills and school and car insurance and tuition. And so if she's working in a position like she's in, it seems like the situation is pretty desperate and that she's basically begging for someone to not necessarily sweep her off her feet and like have that Cinderella ending, but for her to not have to worry.

\section{Discussion}

Cycling, choosing, accessing, identifying, relating, and intersecting made up the process by which participants constructed social class differences among women. No marked major differences were noted by participant major or gender. The research team was able to construct, from participant interviews, dominant plots that indicated what factors make a woman have a lower or higher class status. In the typical participant story line, the woman described as struggling to get by and working as a janitor or in a factory was portrayed as a single mother. This is a fitting description. Over $40 \%$ of American households have women as the primary earner, and $63 \%$ of those homes are single-parent ones (Wang et al., 2013). The average income for a single mother household is between $\$ 17,400$ and $\$ 29,000$, and $28 \%$ of female-headed families have incomes below federal poverty lines (U. S. Census Bureau, 2012; Wang et al., 2013). In participant stories, most often the low-income woman came from poverty in her family of origin and lacked access to education and social support, but also made choices that negatively impact her ability to be upwardly mobile. This also matches the findings of survey data. Those born to lower income families are more likely to fall lower in income than their parents or stay at a similar level (Acs, 2011). The lower-income woman led a stressful life, without support for her and her children, and must balance many roles and expectations. Her personality, though not often described, is thought to be gentle and nice, traits classically associated with the female gender (Brannon, 2004). Interestingly, the participants in this sample seldom referenced race as part of the lower-income woman's identity. It could be in part because the interviewers were students and were emerging in their qualitative interview skills. This reflects a need for the research team to more explicitly probe about the issue of race in further studies. This is in opposition to survey data that reveals considerations of race and racism are a major aspect of American's attitudes about poverty (Foster, 2008; Swank, 2005 ) and indication that women of color are more than twice as likely to be in poverty or working poor than white females (Ahmad \& Iverson, 2013). In short, the study revealed that many college students constructed a relatively realistic story about being poor and female in America, including the stress of gendered stereotypes. Missing from participant analysis was the intersection of race, sexual orientation, and citizenship status.

The middle or upper income woman who works as the vice president of a successful business differed greatly from her low-income counterpart. A great majority of participants indicated that she comes from a family who also has a middle or upper class income, and that she had supportive parents and family. The woman who becomes the vice president has access to education and strong peer support. Access to college education is indeed a major factor in the ability of women to gain or maintain class status (Acs, 2011; Tiamiyu $\&$ Mitchell, 2001). In addition, a woman in a higher class position has more control over her reproductive life and relationships. She may or may not have a husband, but most often 
does not have children. Her personality is strong, focused, and motivated, which matches societal constructions of masculine traits (Brannon, 2004). Like the woman in the lower economic position, she faces work and life balance issues and stress, but she possesses more internal and external resources to meet these challenges.

\section{Implications}

One major standout of the findings is about how participants attribute social class differences among women. The interviews in this study revealed that both structural and individual elements are critical to constructions of class differences among women. This is similar to the Cozzarelli et al. (2001) findings that college students tend to hold cultural and generational beliefs about poverty transmission for women, but also to believe that structural barriers impact a woman's ability to achieve economic mobility. College students in this sample by and large got the "right" story about social class, gender, and oppression. Participants implicitly recognized the realities of the feminization of poverty, and even identified a handful of the core structural reasons women may be poorer. However, many participants believe that women are still to blame in some part for their socioeconomic position through the choices they have made and their family of origin. In general the interview participants saw class mobility in the form of the American dream as a possible but distant goal. Some participants felt that the American dream can be shattered or achieved through relationships, such as marriage or having children. While students may understand that there are structural issues, their adherence to traditional gender roles and belief in the American Dream indicate that there is work to be done in offering a more nuanced perspective of class and gender in America. Men and marriage are still viewed as major devices for women to get ahead. This notion is not without merit. Single women with children are more likely to be downwardly mobile than their married peers (Acs, 2011). In short, children are an expensive liability for a woman struggling to get by. While participants understand some of the realities of class and gender in America, strong belief in exceptionalism and the American dream is still evident.

Participants told stories that noted important similarities among women in all economic situations, including the difficulties of dual participation in workforce and parenting roles. High and low wage work has a plethora of stressful implications for women when intersected with societal role expectations (Froehlich, 2005). In both stories of high and low income, these breadwinner moms (Wang et al., 2013) supported their families while balancing gendered and relational expectations. The resounding consensus from this sample of college students is that it is hard to be a working woman in this country. The turn of phrase "Waiting to be Cinderella'd" offers pause to the now-standard storyline about the struggles of work-life balance for many women. Participants suggest a more modern Cinderella story of a woman who does not necessarily want to be taken care of like a princess in a castle, but perhaps wants a supportive partner to offer some relief from the burdens of managing family, work, and life stressors. The suggestion from participants is not that women categorically wish to return to mid-century gender roles and expectations, but that they may want support to improve quality of life.

The data reveal that participants told half the story about the feminization of poverty. As Foster (2008) suggested, two or more dominant discourses on social issues can exist at 
the same time. This was evident in the stories told by participants, celebrating the freedom of middle and upper class women while also expressing concern about deviations from classic gender roles among single moms and personality shifts in women. This split is evident in the rest of America, too. Pew research indicates that $79 \%$ of Americans do not think women need to return to traditional roles, but $64 \%$ think that the trend of single motherhood is a big problem and 51\% think children are better off staying at home with a mother (Wang et al., 2013). The findings from this study confirm that college students believe that women hold primary responsibility for care of the family unit, an attitude that may contribute to the perpetuation of a gender wage gap (Gittell, 2009). The findings also imply that women are expected to be participants in the work place. Interestingly, very few participants explored the structural deficits, such as a wage gap, lack of supportive mentoring, or discrimination, that impede a woman's ability to gain and maintain high wage work. While participants may understand the struggles faced by women due to social class, few interviewees actively challenged structural factors.

The implications of these findings are two-fold. First, the dominant narrative about the feminization of poverty in this sample may be "right" in some ways, but begs intervention. The realm of social science inquiry is influenced by rhetorical discourse about the intersections of poverty, gender, and race. Participants in this sample ascribed to beliefs that low-income women are vulnerable and in need of aid, but also that they make choices that impact their class status. This implies that it is not enough to teach about the existence of the feminization of poverty, but social work educators and other college professors must explore the causes and consequences. Academics and helping professionals should be cognizant of the impact of these attitudes on people, and challenge the assumptions on both micro and macro levels. This may mean exploring the impact of internalized oppression with clients, or working with community collaborators and organizations on social justice projects aimed at low-income women (Froehlich, 2005). Importantly, it also means continuing to highlight and expose the impact of structural factors in personal lives with the aim of increasing access and skills for women related to their economic positions. Intervention is important, especially in the practice-based field of social work. The concept of economic empowerment, stemming from work to eliminate gender violence, may offer pathways to increasing knowledge among women about social class and mobility (Kristoff \& WuDunn, 2009; Postmus, 2010). Economic empowerment is a process by which an increase in financial literacy, improvement in economic self-efficacy, and more economic self-sufficiency occurs (Postmus, 2010). Preliminary evaluations indicate that empowerment-based programs have had some success in increasing economic resources (Kristoff \& WuDunn, 2010; Postmus, 2010).

The data reveal ongoing shifts in feminist perspective among millennial students. While this research project was not designed specifically to evaluate the impact of feminist thought on college students, some of the current issues in feminism are evident in the sample. Participants did not indicate concern with some of the classic issues of second wave feminism, such as reproductive and legal rights (Baxandall \& Gordon, 2000). Instead, interviewees focused more on what might be called a third wave perspective focused on identity positions, freedom of expression, and broader constructions of family and gender roles (Chamallas, 2010; Snyder, 2008). Much like critiques of the second and third wave 
of feminism, this sample failed, for the most part, to acknowledge the role of intersecting oppression beyond class and gender to include age, ability status, geographic location, and race (Bograd, 1999; Crenshaw, 1993; Danis \& Bhandari, 2010). This suggests that while participants, and perhaps other college students, know that women struggle with issues of social class and work-life balance, more education and awareness are needed to bring to light the influence of structural discrimination and intersectional oppression. An intersectional lens helps to provide/promote awareness of how identity, power, privilege, and oppression come together to shape a person's unique experience and positionality in the world (Bograd, 1999; Crenshaw, 1993; Danis \& Bhandari, 2010). The need for more of an intersectional approach is evident in the lack of discussion about race, sexual orientation, or citizenship status in the participants' responses. A truer picture of what it is to be poor and female in the United States would require attention to intersecting oppressions and privilege. Bringing light to the intersections of oppression, through education, but also in the media, will help to foster more diversity in the dominant discourse about women and social class and perhaps influence attitudes, culture, and policy priorities. This is especially critical in social work, a value-based profession charged with increasing social justice (National Association of Social Workers [NASW], 2008).

Social science research and teaching can benefit from the knowledge gained from this inquiry. As Foster (2008) suggested, class must be looked at as the intersection of not only gender, but race, age, ability and any multitude of identity positions. For researchers and educators, this means approaching gender and social class as related to each other and many other factors. Dominant class attitudes represented in college teaching and research may indicate a seemingly neutral position that in fact matches constructions of male poverty, as found by Cozzarelli, Tagler, and Wlikinson (2002). This study reaffirms that constructions of female social class positions are not the same as male positions, which makes it important for researchers to differentiate the two in projects, and also reveals the need for more data about attitudes on gender-based poverty attitudes that include other forms of intersecting oppression, such as race.

This research was conducted with college seniors, and while not applicable to all populations, indicates that the multiple discourses about attributions to poverty may mean there is a role for educators in helping to shape attitudes on poverty. The important developmental transitions in emerging adulthood include transitioning from beliefs of the family of origin to a more independent lens. This is coupled with new experiences in relationships, careers, and life experiences as well as exposure to diverse viewpoints (Ashford \& LeCroy, 2013). College students, then, are at an age primed for intervention to introduce more dialogue about the structural and gendered nature of social class. Beyond the feminization of poverty is the awareness of action needed to address some of the intersecting challenges faced by women in a variety of social class positions. College education may be one way to introduce change. In short, it is not enough to know there is a feminization of poverty and that it creates problems for women. Social work and other social science researchers, educators and practitioners must illuminate pathways to explore the causes of these oppressions and develop, implement, and evaluate solutions. More exploration in scientific inquiry is needed about the constructions of class and gender among different populations, chiefly those who are experiencing poverty, in order to 
increase the knowledge about how attitudes are formed, and possibly internalized, among people in a state of economic hardship. Through more inquiry, social science researchers can gain insight that will aid in the efforts to eliminate and alleviate poverty.

\section{Limitations}

This study represents a small sample of college seniors at one university who cannot be considered representative of the larger population of students. In addition, data were collected by multiple students and faculty, which may have led to inconsistencies with interviewing skills and methods. Lack of demographic information, in particular race and income of family of origin, makes it difficult to assess potentially important defining characteristics. In addition, participants were not asked to describe the racial or ethnic background of the women in the constructed stories, which could have yielded a more comprehensive response about the impact of intersecting oppressions. More research needs to be done to support these findings, and to explore the meaning behind participant attitudes. In addition, this analysis does not directly ask participants to contrast attitudes on male versus female experiences of poverty, which might have yielded more direct comparisons.

\section{Conclusions}

A sample of 30 Midwestern college seniors were asked to tell stories about two women in different social class positions. The results of this analysis indicate that participants construct social class differences among women as a multi-layered process involving generational cycles, choices, access to resources, personality, relationships, and the impact of other roles. The findings match much of the survey data about attitudes on women and social class positions, but offer a more nuanced understanding of how participants come to these attitudes. While the findings illustrate a basic understanding of structural aspects of the feminization of poverty, more needs to be done to address the impact of these attitudes on women, and increase knowledge of structural barriers among helping professionals. Social science researchers should continue to explore these constructions and how they form in order to work towards social and gender justice.

\section{References}

Abowitz, D. A. (2005). Social mobility and the American Dream: What do college students believe? College Student Journal, 39(4), 716-729.

Acs, G. (2011). Downward mobility from the middle class: Waking up from the American dream. Washington, DC: The Pew Charitable Trusts. Retrieved from http://www.pewtrusts.org/ /media/legacy/uploadedfiles/pcs assets/2011/MiddleClas sReportpdf.pdf?la=en

Adeola, F. O. (2005). Racial and class divergence in public attitudes and perceptions of poverty in the USA: An empirical study. Race, Class \& Gender, 12(2), 53-80.

Ahmad, F., \& Iverson, S. (2013). The state of women of color in the United States: Too many barriers remain for this growing and increasingly important population. 
Retrieved from the Center for American Progress website: http://www.americanprogress.org/wp-content/uploads/2013/10/StateOfWomenColor$\underline{1 . p d f}$

American Association of University Women [AAUW]. (2014a). How does race affect the gender wage gap? Retrieved from http://www.aauw.org/2014/04/03/race-and-thegender-wage-gap/

AAUW. (2014b). The simple truth about the gender pay gap. Retrieved from: http://www.aauw.org/research/the-simple-truth-about-the-gender-pay-gap/

Annells, M. (1997). Grounded theory method, part II: Options for users of the method. Nursing Inquiry, 4, 176-180.

Ashford, J. B., \& LeCroy, C. W. (2013). Human behavior in the social environment: A multidimensional perspective. Belmont, CA: Brooks/Cole.

Baxandall, R., \& Gordon, L. (Eds.). (2000). Dear sisters: Dispatches from the women's liberation movement. New York, NY: Basic Books.

Birks, M., \& Mills, J. (2011). Grounded theory: A practical guide. London: Sage.

Bograd, M. (1999). Strengthening domestic violence theories: Intersections of race, class, sexual orientation, and gender. Journal of Marital and Family Therapy, 25(3), 275289.

Brannon, L. (2004). Gender: Psychological perspectives. Boston, MA: Allyn \& Bacon.

Chamallas, M. (2010). Past as prologue: Old and new feminisms. Michigan Journal of Gender \& Law, 17(1), 157-174.

Charmez, K. (2006). Constructing grounded theory: A practical guide through qualitative analysis. London: Sage.

Corbin, J., \& Strauss, A. (2008). Basics of qualitative research: Techniques and procedures for developing grounded theory $\left(3^{\text {rd }}\right.$ ed.). Thousand Oaks, CA: Sage.

Cozzarelli, C., Tagler, M. J., \& Wilkinson, A.V. (2002). Do middle-class students perceive poor women and poor men differently? Sex Role, 47(11/12) 519-529.

Cozzarelli, C., Wilkinson, A., \& Tagler, M. J. (2001). Attitudes toward the poor and attributions for poverty. Journal of Social Issues, 57(2), 207-227.

Crenshaw, K. (1993). Mapping the margins: Intersectionality, identity politics, and violence against women of color. Stanford Law Review, 43, (6), 1241-1298.

Danis, F. S., \& Bhandari, S. (2010). Understanding domestic violence: A primer. In L. L. Lockhart \& F. S. Danis's (Eds.), Domestic violence: Intersectionality and culturally competent practice (pp. 29-66). New York, NY: Columbia University Press.

Davidson, T. C. (2009). Attributions for poverty among college students: The impact of service-learning and religiosity. College Student Journal, 43(1), 136-144. 
Dwyer, R. E. (2013). The care economy? Economic restructuring, and job polarization in the U. S. labor market. American Sociological Review, 78(3), 390-416.

Foster, C. H. (2008). The welfare queen: Race, gender, class, and public opinion. Race, Gender, \& Class, 15(3/4), 162-179.

Froehlich, J. (2005). Steps toward dismantling poverty for working, poor women. Work, 24, 401-408.

Gittell, R. (2009). Constrained choices and persistent gender inequality: The economic status of working women in a high-income, low-poverty state with lessons for others. American Behavioral Scientist, 53(2), 170-192.

Hostetter, C., Sullenberger, S. W., \& Wood, L. (2013). The key to learning: Engaging undergraduate students in authentic social work research. The Journal of Baccalaureate Social Work, 18, 47-62.

Kristoff, N. D., \& WuDunn, S. (2009). Half the sky: Turning oppression into opportunity for women worldwide. New York, NY: Random House.

National Association of Social Workers. (2008). Code of ethics. Retrieved from http://socialworkers.org/pubs/code/default.asp

Postmus, J. L. (2010, October). Economic empowerment of domestic violence survivors. Harrisburg, PA: VAWnet, a project of the National Resource Center on Domestic Violence/Pennsylvania Coalition Against Domestic Violence. Retrieved from http://vawnet.org/Assoc_Files_VAWnet/AR_EcoEmpowerment.pdf

Richards, T. N., Garland, T. S., Bumphus, V. W., \& Thompson, R. (2010). Personal and political? Exploring the feminization of the American homeless population. Journal of Poverty, 14(1), 97-115.

Snyder, R. C. (2008). What is third-wave feminism? A new directions essay. Signs: Journal of Women in Culture and Society, 34(1), 175-196.

Swank, E. (2005). Welfare-spending judgments through class, race, and gender lenses: Exploring the influence of stratification beliefs, racial attitudes, and gender norms. Journal of Poverty, 9(4), 49-72.

Tiamiyu, M., \& Mitchell, S. (2001). Welfare reform: Can higher education reduce the feminization of poverty? The Urban Review, 33(1), 47-56.

U. S. Bureau of Labor Statistics. (2012). A profile of the working poor, 2010. U. S. Department of Labor (Report No. 1035). Retrieved from http://www.bls.gov/cps/cpswp2010.pdf

United States Census Bureau. (2012). People in poverty by selected characteristics: 2010 and 2011. Retrieved from https://www.census.gov/hhes/www/poverty/data/incpovhlth/2011/table3.pdf 
Wang, W., Parker, K., \& Taylor, P. (2013, May). Breadwinner moms. Pew Social \& Demographic Trends. Washington, DC: Pew Research Center. Retrieved from http://www.pewsocialtrends.org/files/2013/05/Breadwinner_moms final.pdf

\section{Author note}

Address correspondence to: Leila Wood, LMSW, PhD, Assistant Professor, Texas State University School of Social Work, 601 University Drive, HPB 150A, San Marcos, TX 78666. Email: leila_wood@txstate.edu 